\title{
Development of Traditional Sport Game Model "Bentengan" for Student's Physical Fitness in Sports and Health Physical Education Learning (Case Study on Class IV MI Students of Maduran Lamongan District)
}

\author{
Moh. Syobil Birri', Agus Hariyanto ${ }^{2}$, Abdul Rachman Syam Tuasikal ${ }^{3}$ \\ ${ }^{1,2,3}$ Sport Education Department, Universitas Negeri Surabaya, Indonesia \\ shobil01moh@gmail.com
}

\begin{abstract}
The purpose of this development research is to improve physical fitness in the Physical Education learning process. The development of the traditional sports game model "Bentengan" is carried out in several stages: needs analysis, product manufacturing, evaluation and validation, phase I trials, product revisions, phase II trials, stage 2 product revisions (last revision). The subjects of this study were fourth grade students of MI from Madrasah Ibtidaiyah in Maduran subdistrict, Lamongan Regency (MIM 10 Gedangan, MIM 1 Pangkatrejo, MI NU Pangkatrejo, and MI Al-Islamiyah Parengan). Expert validation was carried out by two experts. The first phase of the experiment was carried out on 25 students with 1 PJOK teacher and the second stage test was carried out by 71 students with 3 PJOK teachers. The process of collecting data using a questionnaire. This data consists of evaluations for product quality, suggestions for product improvement, and student responses to game models. The result of this research is the product development model of the game "Bentengan" which is packaged in the form of a book to support learning activities and instructions for implementing the game. Based on data from trial results (small group) and field trials (large group), there were no revisions made by researchers on products that had been developed because the percentage of product development reached $89.53 \%$ cognitive aspects with very good categories, $90.39 \%$ affective aspects with very good category, and $88.13 \%$ psychomotor aspects with very good category, so it is feasible to use. Based on the data analysis, it can be concluded that the result of this research is that the product development model of the game "Bentengan" in Penjasorkes learning can be used to improve physical fitness for grade IV Madrasah Ibtidahiyah in Maduran District, Lamongan Regency.
\end{abstract}

Keywords development; tradisional sport; health physical education and sport

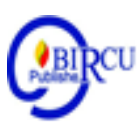

\section{Introduction}

Sports and Health Physical Education (Penjasorkes) is a means of encouraging the development of motor skills, physical abilities, knowledge, sportsmanship, habituation of healthy lifestyles and character building (mental, emotional, spiritual and social) in order to achieve the goals of the national education system.

Physical Education Sport and health is a subject given at a particular school level which is one part of overall education that prioritizes physical activity and fostering alife healthyfor 
growth and development of physically, mentally, socially and emotionally that is harmonious, harmonious and balanced (Depdiknas, 2006: 131). In general secondary education units that serve students with special needs, of course, require special handling in providing the learning process (Muchtar, 2020).

According to Suherman (2009: 7), the goals of physical education are generally declassified into four development goals, namely: physical development. This goal is related to the ability to carry out activities that involve physical strengths from various organs of a person's body (physical fitness), movement development, this goal is related to the ability to move effectively, efficiently, smoothly, beautifully, and perfectly (full skill), mental development. This goal is related to the ability to think and interpret all knowledge about physical education into the environment, social development. This goal is related to the ability of students to adapt to a group or society.

Permendiknas number 22 of 2006 concerning content standards for primary and secondary education units explains that coverage in the physical, sports and health subject groups at SD / MI / SDLB is intended to increase physical potential and instill sportsmanship and awareness of healthy living. According to Yusroni (2019), Sports and Health Physical Education is an education that can be carried out by doing physical sports activities, which aim to maintain and improve physical fitness, in which there are various aspects which include: speed, agility, strength and endurance.

According to Mulyani (2016: 47-48), traditional games are a game of ancestral heritage that is mandatory and needs to be preserved because it contains local wisdom values. In line with this statement, Marzoan \& Hamidi (2017: 46) conclude that "traditional games are activities that are carried out voluntarily and cause pleasure for the perpetrator, governed by game rules which are run based on hereditary tradition '. In line with this statement, "traditional games are games that are played from generation to generation that have a cultural value and are usually played using language and kahsa characteristics from certain areas".

Every form of activity in play and games for children has a positive attitude towards their development. According to Nugroho (2005: 33-34) the values contained in traditional games are democratic values, educational values, personality values, courage values, health values, unity values, and moral values. The elements of cultural values in traditional games according to Dharmamulya (2008) are the value of fun or excitement, the value of freedom, a sense of friends, democratic values, leadership values, a sense of responsibility, the value of togetherness and mutual assistance, the value of obedience, training proficient in arithmetic, and the value of honesty and sportsmanship.

According to Subagiyo (in Mulyani, 2016: 49-52) said that in fact the benefits of traditional games include children being more creative, can be used as therapy for children, developing children's intellectual intelligence, developing emotional intelligence between children's personalities, developing children's logical intelligence, developing Children's kinesthetic intelligence, developing children's natural intelligence, developing children's spatial intelligence, developing children's musical intelligence and developing children's spiritual intelligence.

One of the many traditional games in Indonesia is the bentengan game. The traditional game "fort or bentengan" is a native game of Indonesian culture that has developed in various regions in Indonesia with different game names. This game is called "Fortress" because each team essentially tries to attack each other and defend their fortress, and to avoid being caught / touched by the enemy so they are not captured. 
Physiologists claim that physical fitness is a quantitative expression of a person's physical condition. Physical fitness can be defined as a person's ability to perform tasks that requirework muscular where speed and endurance are the main criteria. A person who is in good physical fitness will be able to fulfill certain physical directions. Physical education experts state that freshness is the total functional capacity of a person to do certain work with good or satisfying results without significant fatigue (Sudarno, 2012:9).

There are several components of physical fitness, both those related to health and those related to skills. According to (Welis, 2013) the components of physical fitness related to health include cardiorespiratory endurance, muscle endurance, muscle strength and body composition. While the components of physical fitness related to skills include speed, agility / dexterity, balance, reaction speed, flexibility and coordination.

Traditional games can be applied as physical education learning in schools by emphasizing aspects of physical fitness that can nourish the body. In addition, traditional games also emphasize aspects of physical education in order to improve cognitive, affective, and psychomotor aspects.

This study aims to determine the development model of the game "bentengan" on the physical fitness of students in learning sports and health physical education, develop games that are effective in learning sports and health physical education and develop games that can improve students' physical fitness in learning sports physical education. and health.

The learning must be prepared by lecturers / trainers with good planning and given in a systematic learning model like Ibrahim's opinion (Giri in Suryono, 2020), namely: State learning planning is an activity to formulate the goals achieved by a learning activity, what methods are used to assess the achievement of these objectives, what material will be delivered, how to convey, and what tools or media are needed.

In addition to the physical education teacher also still exist that use their learning according to what the actual rules of the game and, in fact physical education teacher at the school had to adjust the game to the circumstances and conditions in the school. Allocation of time in physical education lessons exercise and health is still less contribute in improving the physical fitness of students, it is necessary to be a development model of learning that can contribute optimally to achieve the goals of education. (Novianti, 2020).

According to Artha (2020), the purpose of physical education oriented by a learning process for learns to move and learn trough motion. Hope students develops some aspects like fitness, movement, mental, critical thinking, social, self control, healthy life style, and clean environment by choosen and sistematic physic activities. 


\section{Research Method}

The type of research used a development research design. Development research includes the process of looking for novelties and advantages in terms of effectiveness, efficiency and productivity. According to Ardhana (2002: 9) the procedures for implementing research and development are not standard steps that must be followed in a standard manner. Of course, every researcher can choose and determine the most appropriate steps for himself based on the special conditions he faces in the research process. The following are the stages of the development of the game model, which are described in Table 1:

Table 1. Stage of Reseach and Development.

\begin{tabular}{|l|c|l|}
\hline \multicolumn{1}{|c|}{ Stage } & Step & \multicolumn{1}{|c|}{ Activity } \\
\hline $\begin{array}{l}\text { Pre } \\
\text { Development }\end{array}$ & 1 & $\begin{array}{l}\text { Collecting the first data, } \\
\text { the preparation of } \\
\text { proposal research and } \\
\text { analysis of the needs }\end{array}$ \\
\cline { 2 - 3 } & 2 & $\begin{array}{l}\text { Planning the first product, } \\
\text { making the concept of the } \\
\text { game }\end{array}$ \\
\hline Development & 3 & $\begin{array}{l}\text { The first revision product } \\
\text { by advice from specialist } \\
\text { of game }\end{array}$ \\
\cline { 2 - 3 } & 4 & $\begin{array}{l}\text { The first trial by using a } \\
\text { small group }\end{array}$ \\
\cline { 2 - 3 } & 5 & $\begin{array}{l}\text { The second revision } \\
\text { product by the result of } \\
\text { the first trial in a small } \\
\text { group }\end{array}$ \\
\cline { 2 - 3 } & 7 & $\begin{array}{l}\text { The second trial by using } \\
\text { a large group }\end{array}$ \\
\hline Dissemination & 8 & $\begin{array}{l}\text { The last revision product } \\
\text { The result of the } \\
\text { development game for the } \\
\text { fourth grade elementary } \\
\text { school in sub district } \\
\text { Maduran, Lamongan }\end{array}$ \\
\hline
\end{tabular}

The implementation of this research was carried out by 4 Madrasah Ibtidaiyah in Maduran District, Lamongan Regency with the research subject being students IV Madrasah Ibtidaiyah in the District Maduran, Lamongan Regency. In this study, the researchers plan a study period is four months, an outline of the implementation of the research as follows:

a. Pre-Development Stage Research, carried out in June-July 2020.

b. Development Phase Research, conducted in August 2020.

c. The Dissemination Stage Research, was carried out in September 2020.

The test subjects in this development product are as follows:

a. The first trial (small group), namely class IV at MI Muhammadiyah 1 Pangkatrejo with a total of 25 students.

b. The second trials (large groups), namely class IV at MI Muhammadiyah 10 Gedangan, MI NU Pangkatrejo and MAI Al-Islamiyah Parengan with a total of 71 students. 
To determine the success of the development, the data used are instruments in the form of questionnaires, interviews, observations, and field notes. The data analysis technique used in this development research is qualitative analysis techniques and percentage descriptive analysis. The formula that will be used to process data in the form of descriptive percentages according to Sudijono (2008: 40):

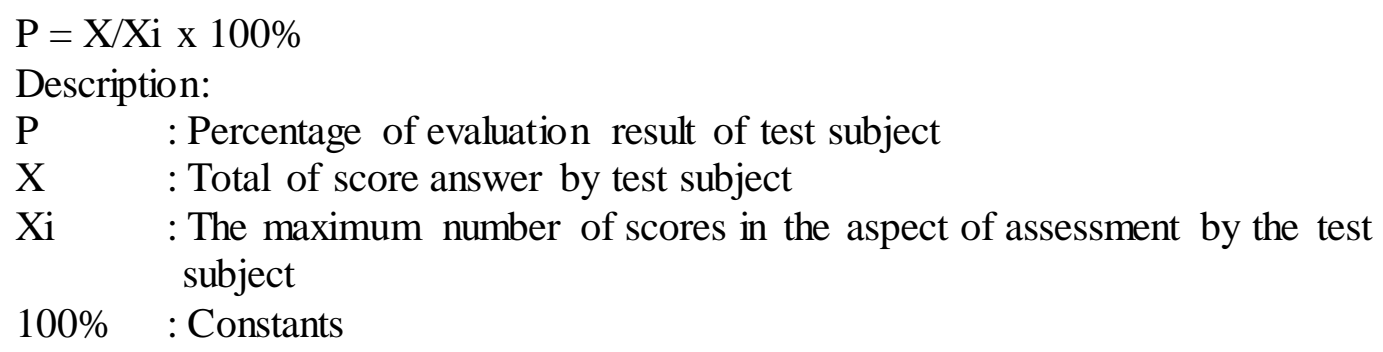

The bentengan game model developed is called to be successful and in accordance with the score criteria level of $60 \%$, then this media can be used as a medium of learning in teaching and learning activities.

To facilitate conclusions on the results of the analysis of the percentage level of attractiveness of development products, the criteria for classification according to Arikunto (2009: 245) in Table 2 are as follows:

Table 2. Eligibility Criteria for Learning Media

\begin{tabular}{|l|l|l|}
\hline \multicolumn{1}{|c|}{ Percentage } & Explanation & \multicolumn{1}{c|}{ Criteria } \\
\hline $80-100 \%$ & Excellent & Be used \\
\hline $66-79 \%$ & Good & Be used \\
\hline $56-65 \%$ & Sufficient & Conditionally used \\
\hline $40-55 \%$ & Deficient & Repaired \\
\hline $30-39 \%$ & Failed & Replaced \\
\hline
\end{tabular}

The results of the development of game products with a game development approach with the category of innovation games on learning materials for Physical Education, Sports, and Health in grade IV Elementary School will be described as follows:

\section{Discussion}

\subsection{Results of Game Product Development}

This development game will be made by modifying the game with changing game tools, gameplay and game rules which aims to improve the physical fitness of students. The game tools are in the form of a rectangular field with a size of $26 \mathrm{mx} 15 \mathrm{~m}$, a circular fort area with a diameter or diameter of $1 \mathrm{~m}$, with a distance of $3 \mathrm{~m}$ from the back line and 7.5 side lines. The field is marked with a $5 \mathrm{~cm}$ line, the prison area is rectangular in shape, $1.5 \mathrm{~m}$ long and $1 \mathrm{~m}$ wide. Meanwhile, the fort is a pole measuring $2 \mathrm{~m}$. To develop this game an arrangement of plastic cups is added to form a pyramid fortress. 
The way the game develops in this game is almost the same as the way the previous clash was played, it's just that in developing this clash before attacking the opponent's fortress, each team has to build a fort made of plastic glass. The rules of the game in developing this game are almost the same as the rules of the previous bentengan game, it's just that in the development of this bentengan the addition of the goal of the game is the first to build a fortress for each team and the second is to attack the opponent's main fortress.

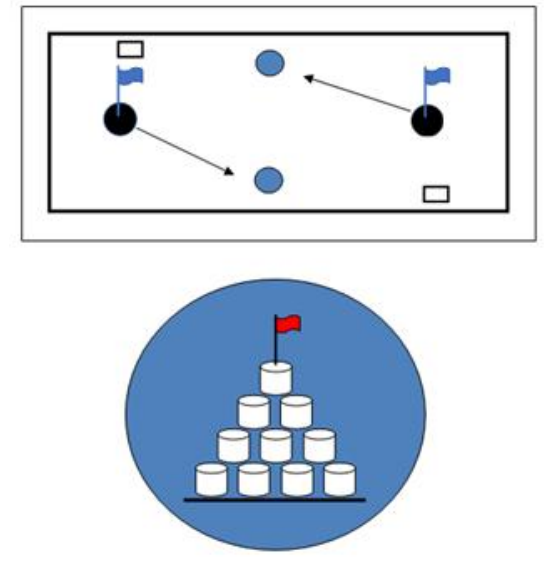

Figure 1. Sketch of Development Bentengan

\subsection{Analysis of the Needs}

Researcher makes a questionnaire with several questions including: (1) The suitability of the materials given by the Sports and Health Physical Education teacher studied? (2) The level of convenience of the material provided by the Sports and Health Physical Education Teacher? (3) Is the material provided by the teacher able to make friends to actively learn? (4) Was the material provided by the teacher enjoyable? (5) Do other subjects include physical education in Sports and Health? (6) Has the Sports and Health Physical Education teacher ever taught games that include other subject matter for this semester? (7) Do Sports and Health Physical Education Teachers apply games in Physical Education learning? (8) Do you agree if a game is developed in Physical Education learning?

The results of the answers to these questions can be concluded that most of the material taught by the teacher is soccer $(73.96 \%)$, most students also stated that learning was not fun $(56.25 \%)$, so it did not make students more active in the learning process $(51,04 \%)$. While the results obtained from the teacher's questionnaire can be concluded that the teacher lacks application of the game approach, for teacher learning resources only use the teacher's handbook. All the 4 Madrasah teachers stated that they needed alternative learning with a game approach, and supported the development research with a game approach.

\subsection{The Revised Product Review}

Advendi Kristiyandaru, M.Pd who is a lecturer in Sports Education at the Faculty of Sports Science, State University of Surabaya, the size of the field should be adjusted to MI students with a length of $26 \mathrm{~m}$ and a width of $15 \mathrm{~m}$ and infrastructure should be made of equipment that is not permanent and suitable for MI students.

According to Dr. Abd Cholid, M.Pd, who is a lecturer in Sports Education at the Postgraduate Masters of PGRI Adi Buana University Surabaya, the construction of the fort 
uses plastic cups and is arranged in pyramids to make it easier for students to do it and the game rules are made clearly and in a book so that the teacher can use it and students.

\subsection{Field Test Data Analysis}

According to Pangrazi (2000: 6) states that physical education is a stage of a general education program that contributes to the overall growth and development of students, especially through movement experiences. This is a learning program that pays attention to all learning domains, namely: psychomotor, cognitive, and affective.

Field trials have been carried out through several stages, namely stage 1 small group trials and stage 2 large group trials. Small group trials with instruments of 9 cognitive questions, 10 affective questions, and 8 psychomotor questions for 25 grade IV students and 10 questions for 1 Physical Education teacher. While the large group trial with instruments consisted of 9 cognitive questions, 10 affective questions, and 8 psychomotor questions for 71 grade IV students and 10 questions for 3 Physical Education teachers.

Table 3. Recapulation of Small Group Trial Results $(n=25)$ Students and $(n=1)$ Physical Education Teacher

\begin{tabular}{|c|c|c|c|c|c|}
\hline No & Subject & $\begin{array}{c}\text { Cognitive } \\
\text { Aspect }\end{array}$ & $\begin{array}{c}\text { Affective } \\
\text { Aspect }\end{array}$ & $\begin{array}{c}\text { Psychomotor } \\
\text { Aspect }\end{array}$ & $\begin{array}{c}\text { Average } \\
(\%)\end{array}$ \\
\hline 1 & Students & 90,56 & 91,8 & 89,88 & 90,74 \\
\hline 2 & Teachers & & & 87,5 \\
\hline Avarage (\%) & & 89,12 \\
\hline \multicolumn{2}{|c|}{ Category } & & Excellent \\
\hline
\end{tabular}

Table 4. Recapulation of Large Group Trial Results $(n=71)$ Students and $(n=3)$ Physical Education Teachers

\begin{tabular}{|c|c|c|c|c|c|}
\hline No & Subject & $\begin{array}{c}\text { Cognitive } \\
\text { aspect }\end{array}$ & $\begin{array}{c}\text { Affective } \\
\text { aspect }\end{array}$ & $\begin{array}{c}\text { Psychomotor } \\
\text { aspect }\end{array}$ & $\begin{array}{c}\text { Avarage } \\
(\boldsymbol{\%})\end{array}$ \\
\hline 1 & Students & 89,53 & 90,39 & $89,8899,13$ & 89,35 \\
\hline 2 & Teachers & & 86,67 \\
\hline \multicolumn{2}{|c|}{ Avarage (\%) } & & 88,01 \\
\hline \multicolumn{2}{|c|}{ Category } & & Excellent \\
\hline
\end{tabular}

Based on data on the results of trials (small groups) and field trials (large groups) no revisions were made by researchers on products that have been developed because remembering the percentage reaches $89.53 \%$ of cognitive aspects with excelent categories, $90.39 \%$ of affective aspects with excellent categories, and $88.13 \%$ of psychomotor aspects with excellent categories, so it is feasible to use.

While the results ofwhich were carried out by class IV students of MI Muhammadiyah 1 Pangkatrejo after getting action with the Bentengan game had increased, it is known that based on the implementation of the pre-test physical fitness, the average level of physical fitness was 14.48 , while at the time of the post test the mean size was 18,24 . It turned out that after being given the treatment of the Bentengan development game, the mean size of the 
TKJI test result data was an increase of 3.76. So that the learning of Sports and Health Physical Education in class IV MI Muhammadiyah 1 Pangkatrejo, Maduran District, Lamongan Regency has improved both in terms of Physical Fitness.

\section{Conclusion}

The development product in this study contains the Bentengan game model as a support in learning. This development research produces a game that has proven advantages and there are also weaknesses including:

\subsection{Advantages}

The advantages of the product development of a game model for Physical Education, Sports and Health subjects for grade IV Madrasah Ibtidaiyah students include:

a. This game model plays a role in increasing student activity and participation.

b. Not neglecting the elements contained in the goals of Physical Education, Sports and Health.

c. Support the achievement of learning objectives both mastery of movement, attitudes and student knowledge.

d. The game is easy for students to understand and they feel happier if the learning activities are delivered using a play approach.

e. Introducing traditional games into Physical Education, Sports and Health learning.

\subsection{Weaknesses}

Product development certainly cannot be separated from the shortcomings and weaknesses, among these weaknesses are:

a. The product in this development is limited to rudimentary regulations for the primary school level.

b. The facilities and infrastructure used in product development are still imperfect.

\section{References}

Ardhana, Wayan. (2002). Development Research Concepts in the Field of Education and Learning. Malang: State University of Malang.

Arikunto, S. (2009). Research Procedure A Practice Approach. Jakarta: Rineka Cipta.

Artha, A.A., T Syam, A.R., Priambodo, A. (2020). The Application of Teams Games Tournament (TGT) and Teaching Game for Understanding (TGfU) Learning Models on Learning Motivation and Volley Ball Passing Skills. Budapest International Research and Critics in Linguistics and Education (BirLE) Journal Vol 3 (1): 46-53.

Dharmamulya, Sukirman. (2008). Javanese Traditional Games. Yogyakarta: Kepel Press

Directorate General of Education, Ministry of National Education. (2006). Permendiknas No 22 of 2006 concerning Content Standards. Jakarta: Depdiknas.

Marzoan \& Hamidi. (2017). "Traditional Games as Extracurricular Activities to Improve StudentsSocial Competence"" Volume. 2, No, 1.

Muchtar, I., Kartiko, D.C., and Tuasikal, A.R. (2020). Development of a Long Jump Education Model through a Game Approach to Improve Basic Movement for Students with Disabilities Grahita in Inclusive Schools at SMP Negeri 28 Surabaya. Budapest International Research and Critics in Linguistics and Education (BirLE) Journal Vol 3 (3): 1479-1488. 
Mulyani, Novi. (2016). Super fun Indonesian traditional games. Yogyakarta: DIVA Press.

Novianti, D., Mahardika, I.M.S., and Tuasikal, A.R. (2020). Improvement of Physical, Honesty, Discipline and Cooperation in Class IV Elementary School Students through Circuit Training Learning Model. Budapest International Research and Critics in Linguistics and Education (BirLE) Journal Vol 3 (1): 244-250.

Nugroho A. (2005). Traditional Games for Children as a Source of Ideas in Graphic Art Creation. Surakarta: UNS Press

Pangrazi Robert P. 2004. Dynamic Physical Education Elementary School Children. San Francisco. Benjamin Cummings.

Sudarno. (2012). Physical Fitness Education. Jakarta: Depdikbud Dirjen Dikti.

Sudijono. (2008). Introduction to Educational Evaluation. Jakarta: Raja Grafindo.

Suherman. (2009). Revitalization of Teaching in Physical Education. Bandung: FPOK UPI

Suryono, Mahardika, I.M.S., and Tuasikal, A.R. (2020). Pride Learning Model in Order to Improve the Physical Fitness of Indonesian Naval Academy Cadets. Budapest International Research and Critics in Linguistics and Education (BirLE) Journal Vol 3 (1): 235-243.

Welis, Wilda, Rifki MS. (2013). Nutrition for Physical Activity and Fitness. Padang: Sukabina Press.

Yusroni, M., T Syam, A.R., Khamidi, A. (2019). The Effect of Individual and Group Jump Rope Games on Physical Fittnes and Motivation. Budapest International Research and Critics in Linguistics and Education (BirLE) Journal Vol 2 (4): 648-652. 